\title{
Morphogenesis and tiller density of Aruana grass managed at different heights under sheep grazing
}

\section{Morfogênese e densidade de perfilhos do capim-Aruana manejado em diferentes alturas sob pastejo de ovinos}

\author{
Renata Negri ${ }^{1 *}$; Guilherme Batista dos Santos ${ }^{2}$; Vicente de Paulo Macedo ${ }^{3}$; Magali \\ Floriano da Silveira ${ }^{3}$; Leticia Wlodarski ${ }^{4}$; Sabrina Kluska ${ }^{5}$
}

\begin{abstract}
This study aimed to assess the morphogenic characteristics and tiller density of Aruana grass managed at different heights under sheep grazing. Aruana grass was managed at four mean heights $(12,15,20$, and $25 \mathrm{~cm}$ ) distributed in a randomized block design with three replications, totaling 12 paddocks of $250 \mathrm{~m}^{2}$ each. Twenty-four crossbred Dorper x Santa Inês lambs, with mean age and weight of $60 \pm 15$ days and $16.69 \pm 2.70 \mathrm{~kg}$, respectively, were randomly distributed in the treatments. Five tillers were demarcated per paddock for measuring morphogenic variables. A representative area in the paddock was used for counting the number of tillers. No differences $(\mathrm{P}>0.05)$ were observed for leaf appearance rate, leaf elongation rate, stem elongation rate, leaf senescence rate, final leaf length, and leaf life span between the assessed heights. Phyllochron was longer at the height of $25 \mathrm{~cm}$ when compared to 15 and $20 \mathrm{~cm}$ $(19.35,12.11$, and 12.75 days, respectively). The number of live leaves was higher at heights of 12,15 , and $20 \mathrm{~cm}$ when compared to $25 \mathrm{~cm}(3.99,4.35,4.15$, and 2.86, respectively). The number of basal and aerial tillers presented no variation $(\mathrm{P}>0.05)$ between canopy heights. Management heights from 15 to $20 \mathrm{~cm}$ allowed a higher number of live leaves and a shorter phyllochron in Aruana grass pastures managed for sheep. Canopy height management did not influence other morphogenic characteristics and tiller density.
\end{abstract}

Key words: Leaf appearance. Leaf life span. Phyllochron. Number of live leaves.

\section{Resumo}

O objetivo com o trabalho foi avaliar as características morfogênicas e a densidade de perfilhos do capim-Aruana manejado em diferentes alturas sob pastejo de ovinos. Em 12 piquetes de $250 \mathrm{~m}^{2}$ cada, o capim-Aruana foi manejado em quatro alturas médias (12, 15, 20 e $25 \mathrm{~cm})$, distribuídas em um delineamento experimental de blocos casualizados, com três repetições para cada tratamento. Utilizouse vinte e quatro borregas mestiças das raças Dorper x Santa Inês com idade e peso médio de $60( \pm 15)$

1 Discente do Curso de Doutorado, Programa de Pós-Graduação em Zootecnia, Universidade Federal do Rio Grande do Sul, UFRGS, Porto Alegre, RS, Brasil. E-mail: rn.negri@yahoo.com

2 Zootecnista, M.e em Zootecnia, Universidade Tecnológica Federal do Paraná, UTFPR, Dois Vizinhos, PR, Brasil. E-mail: guilherme_bs@yahoo.com.br

3 Profs., Curso de Zootecnia, UTFPR, Dois Vizinhos, PR, Brasil. E-mail: vicentepmacedo@utfpr.edu.br; magalisilveira@utfpr. edu.br

4 Discente do Curso de Doutorado, Programa de Pós-Graduação em Zootecnia, Universidade Federal de Santa Maria, UFSM, Santa Maria, RS, Brasil. E-mail: lewlodarski@hotmail.com

5 Discente do Curso de Doutorado, Programa de Pós-Graduação em Genética e Melhoramento Animal, Universidade Estadual Paulista Júlio de Mesquita Filho, UNESP, Jaboticabal, SP, Brasil. E-mail: sabrinakluska@gmail.com

* Author for correspondence 
dias e 16,69 $( \pm 2,70) \mathrm{kg}$, respectivamente, distribuídas aleatoriamente nos tratamentos. Para mensuração das variáveis morfogênicas, foram demarcados cinco perfilhos por piquete. Para contagem do número de perfilhos, foi escolhida uma área representativa do piquete. Não foram observadas diferenças (P > $0,05)$ para a taxa de aparecimento foliar, taxa de alongamento foliar, taxa de alongamento do colmo, taxa de senescência foliar, comprimento final de folha inteira e duração de vida das folhas entre as alturas avaliadas. O filocrono foi maior na altura de $25 \mathrm{~cm}$ quando comparado às alturas de 15 e $20 \mathrm{~cm}(19,35$, 12,11 e 12,75 dias, respectivamente). O número de folhas vivas foi superior nos tratamentos de $12,15 \mathrm{e}$ 20 , quando comparados ao de $25 \mathrm{~cm}(3,99,4,35,4,15$ e 2,86, respectivamente). O número de perfilhos basais e aéreos não variaram $(\mathrm{P}>0,05)$ entre as alturas de dossel. Alturas de manejo entre 15 e $20 \mathrm{~cm}$ permitem maior número de folhas vivas e menor filocrono em pastagens de capim-Aruana manejada para ovinos. A altura de manejo do dossel não influenciou nas demais características morfogênicas e densidade de perfilhos.

Palavras-chave: Aparecimento foliar. Duração de vida da folha. Filocrono. Número de folha viva.

\section{Introduction}

Livestock grazing viability depends on the correct exploitation of pasture and its resources (GOMIDE; GOMIDE, 1999). The importance of determining the height, animal load, and dynamics of plant morphogenesis process is related to the influence of these factors on canopy structure and, consequently, the quantity and quality of the harvested forage. Among the management criteria, pasture height is an essential tool for ideal system conduction.

Pasture height is an important tool and indicator of management because it can be easily verified under field situations, besides showing a direct relationship with plant morphogenesis and structure. The lower the management height is, the higher the amount of light received at the plant base, stimulating the appearance of new vegetative tillers (SOUSA et al., 2013). However, a higher management height may guarantee a higher forage mass during winter, but with many stems and dead tissues (VILELA et al., 2012). Moreover, pasture height is associated with morphophysiological parameters, being effective as a management tool and variable according to the animal species to be explored.

Morphogenesis consists of the dynamics of generation and expansion of plant organs in time and space, characterizing canopy structure (LEMAIRE; CHAPMAN, 1996). Knowing the structural behavior of forage plants allows an adequate management recommendation to maximize pasture utilization, given the possibility of visualizing the seasonal forage production curve and directing possible management strategies to be adopted in production systems (ALEXANDRINO et al., 2011).

Among the forage plants used in current production systems, Panicum maximum Jacq. cv. Aruana has a high carrying capacity and high nutritional value (SILVA et al., 2009). The open and erect leaf architecture associated with high forage yield and excellent acceptability by animals makes Aruana grass an ally of Brazilian livestock (POMPEU et al., 2010). Aruana grass has been widely disseminated and recommended for sheep production systems due to its palatability and canopy structure (BIACHINI et al., 1999). Another factor that enhances the use of the Aruana grass by sheep is the height management, which can be smaller due to species particularities. However, few studies have investigated the adequate use of Aruana grass for sheep aiming at a balance in the plant-animal system given that pasture height influences its structure and hence its morphogenic characteristics. In this sense, this study aimed to assess four heights of Aruana grass managed for sheep grazing under continuous stocking and its reflection on morphogenic variables and tiller density. 


\section{Material and Methods}

The experiment was carried out from November 2012 to January 2013 at the Sheep and Goat Research and Teaching Unit of the Federal University of Technology - Paraná (UTFPR), located in Dois Vizinhos, PR, at the geographical coordinates $25^{\circ} 42^{\prime}$ $\mathrm{S}$ and $53^{\circ} 03^{\prime} \mathrm{W}$ and altitude of $520 \mathrm{~m}$ above sea level (NATIONAL INSTITUTE OF METEOROLOGY - INMET, 2013). The soil is classified as a clay textured dystrophic Red Latosol, according to Brazilian Agricultural Research Corporation Embrapa (1999). The regional climate is classified as Cfa, i.e., a subtropical humid mesothermal climate with a mean annual precipitation of $1,953 \mathrm{~mm}$ and mean annual temperatures of 25.2 (maximum) and $14.7^{\circ} \mathrm{C}$ (minimum) (ALVARES et al., 2013). Figure 1 shows the maximum and minimum temperatures and precipitation during the experimental period.

Figure 1. Meteorological data during the experiment.

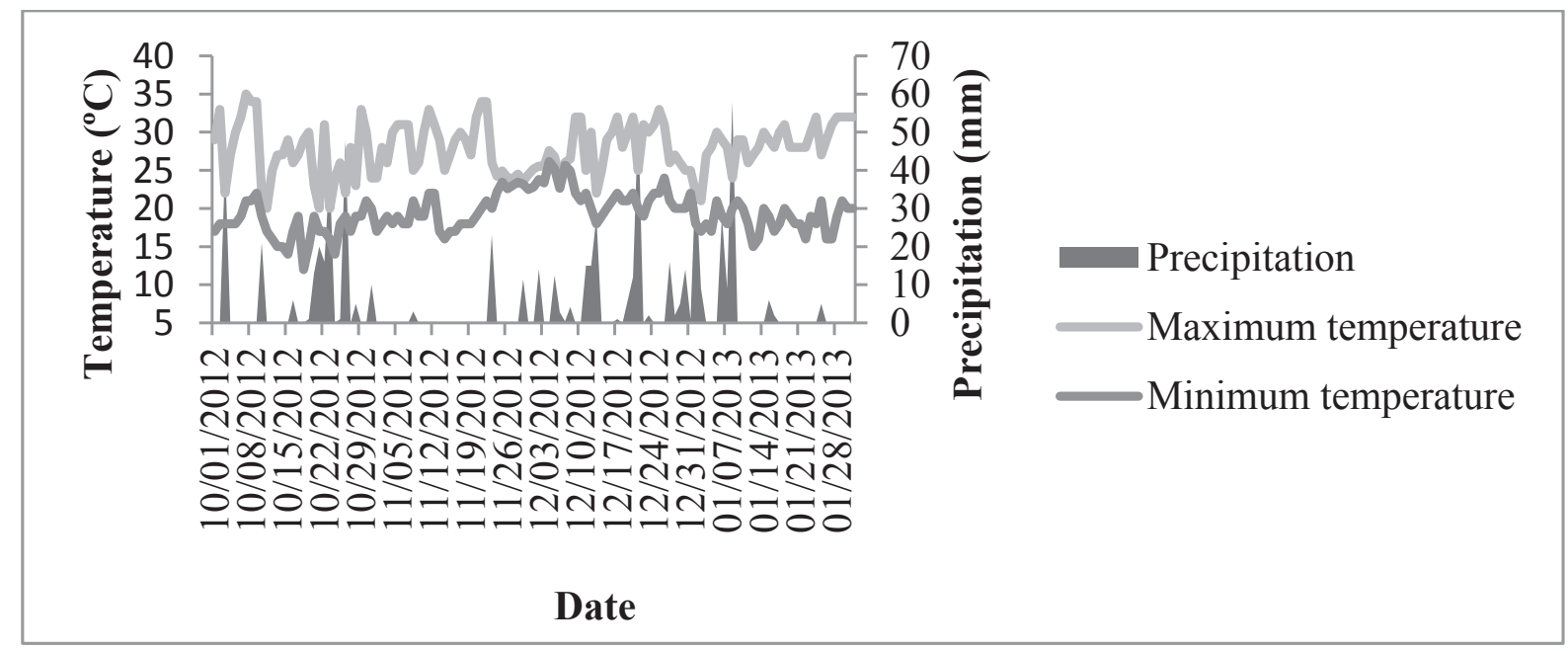

Aruana grass (Panicum maximum Jacq. cv. Aruana) had been established for two years in the area when the experiment was carried out using 12 paddocks of $250 \mathrm{~m}^{2}$. Four management heights were intended: $10,15,20$, and $25 \mathrm{~cm}$, but pasture heights of $12,15,20$, and $25 \mathrm{~cm}$ (treatments) were reached. These treatments were distributed in a randomized block design with three replications. The initial leveling of heights was performed with a brush cutter. An adaptation period of 21 days was set after treatment heights were established. After adaptation, the experimental period lasted 63 days, divided into three periods of 21 days for data collection. Fertilization of $48.6 \mathrm{~kg} \mathrm{~N} \mathrm{ha}^{-1}$ was carried out at the beginning of each period based on soil analysis.
Twenty-four crossbred Dorper x Santa Inês lambs with a mean age of $60 \pm 15$ days and mean weight of $16.69 \pm 2.70 \mathrm{~kg}$ were randomly distributed in the treatments to maintain forage height, being two tester lambs per paddock. Grazing method consisted of the continuous stocking with variable stocking rate, using the technique described by Mott and Lucas (1952). Control of heights was monitored using a ruler graduated in millimeters at ten points per paddock and three times a week. Regulatory animals of the same species, breed, and age were used when necessary (Table 1).

Five tillers were demarcated per plot using colored threads to assess the morphogenic characteristics, totaling fifteen tillers per treatment distributed in a 
transect, according to the methodology of Carrère et al. (1997). These transects were distributed inside the paddocks at locations representing the mean height. Tillers were assessed twice a week with a ruler graduated in millimeters. New tillers were demarcated at the end of each period, following the same criteria described. Stem length and number of mature and growing leaf blades $(\mathrm{cm})$ were classified according to their condition (senescent or not and intact or defoliated) at each assessment, according to the methodology proposed by Lemaire and Chapman (1996): leaf appearance rate (LAR), defined as the number of leaves emerged per tiller divided by the number of days of the assessment period; phyllochron (PHY), which is the inverse of the leaf appearance rate; leaf elongation rate (LER), obtained by the sum of all leaf blade elongation divided by the number of days of the assessment period; stem elongation rate (SER), which is the sum of all stem elongation divided by the number of days of the assessment period; leaf senescence rate (LSR), defined as the ratio between the sum of the senesced leaf blade lengths in the tiller and the number of days of the assessment period; number of live leaves (NLL), obtained by counting the number of expanding and expanded leaves, not considering the senescent leaves of each tiller; final leaf length (FLL), obtained by measuring only fully expanded leaves of the assessed tillers from their insertion in the fully expanded ligule to the leaf apex, not considering leaves in expansion; and leaf life span (LLS), defined as the period from leaf appearance to its death, which is estimated by the equation LLS $=\mathrm{NLL} \times \mathrm{PHY}$.

Table 1. Mean heights of Panicum maximum Jacq. Aruana pasture managed at different heights under lamb grazing.

\begin{tabular}{|c|c|c|c|c|}
\hline Height & 12 & 15 & 20 & 25 \\
\hline \multicolumn{5}{|c|}{ Adaptation } \\
\hline$\mu 1-6$ days* & 12.0 & 15.0 & 20.1 & 25.1 \\
\hline$\mu$ 7-13 days & 12.3 & 14.7 & 20.4 & 25.4 \\
\hline$\mu$ 14-21 days & 12.2 & 14.7 & 20.3 & 25.2 \\
\hline Mean & 12.2 & 14.8 & 20.3 & 25.2 \\
\hline \multicolumn{5}{|c|}{ 1st period } \\
\hline$\mu$ 1-6 days & 12.2 & 14.7 & 20.3 & 25.2 \\
\hline$\mu$ 7-13 days & 11.7 & 15.2 & 19.7 & 24.8 \\
\hline$\mu$ 14-21 days & 11.8 & 15.1 & 19.8 & 24.8 \\
\hline Mean & 11.9 & 15.0 & 19.9 & 24.9 \\
\hline \multicolumn{5}{|c|}{ 2nd period } \\
\hline$\mu 1-6$ days & 11.8 & 15.1 & 19.8 & 24.8 \\
\hline$\mu$ 7-13 days & 12.4 & 14.7 & 20.3 & 24.9 \\
\hline$\mu$ 14-21 days & 12.3 & 14.7 & 20.1 & 25.0 \\
\hline Mean & 12.2 & 14.8 & 20.1 & 24.9 \\
\hline \multicolumn{5}{|c|}{ 3rd period } \\
\hline$\mu 1-6$ days & 12.2 & 14.7 & 20.1 & 25.0 \\
\hline$\mu 7-13$ days & 11.6 & 15.3 & 19.8 & 25.1 \\
\hline$\mu$ 14-21 days & 11.6 & 15.5 & 20.1 & 25.2 \\
\hline Mean & 11.8 & 15.2 & 20.0 & 25.1 \\
\hline Overall mean & 12.03 & 14.95 & 20.08 & 25.03 \\
\hline
\end{tabular}

$\mu^{*}=$ mean of the week. 
A frame with an area of $0.0625 \mathrm{~m}^{2}$ was used to count the tillers on the 15 th after the beginning of each period to determine the population density of basal and aerial tillers. For this, two assessments were performed per paddock considering an area representative of the mean height of treatments.

The data were submitted to analysis of variance and F-test at 5\% significance. A regression analysis was also performed using the statistical program $\mathrm{R}$ (R CORE TEAM, 2013).

\section{Results and Discussion}

Leaf appearance rate (LAR), leaf elongation rate (LER), leaf senescence rate (LSR), final leaf length (FLL), leaf life span (LLS), and stem elongation rate (SER) were not influenced by pasture management heights $(\mathrm{P}>0.05$; Table 2$)$.

Table 2. Mean values for leaf appearance rate (LAR, leaf tiller ${ }^{-1}$ day $\left.{ }^{-1}\right)$, leaf elongation rate (LER, $\mathrm{cm} \mathrm{tiller}^{-1}$ day $^{-1}$ ), leaf senescence rate (LSR, $\mathrm{cm}_{\text {tiller }}^{-1} \mathrm{day}^{-1}$ ), final leaf length (FLL, $\mathrm{cm} \mathrm{tiller}^{-1}$ ), leaf life span (LLS, day), stalk elongation rate (SER, cm tiller ${ }^{-1}$ day $^{-1}$ ), phyllochron (PHY, day leaf ${ }^{-1}$ tiller $^{-1}$ ), and number of live leaves (NLL) of Panicum maximum Jacq. Aruana pasture managed at different heights under lamb grazing.

\begin{tabular}{|c|c|c|c|c|c|}
\hline \multirow{2}{*}{ Variable } & \multicolumn{4}{|c|}{ Forage height $(\mathrm{cm})$} & \multirow{2}{*}{ MSE* } \\
\hline & 12 & 15 & 20 & 25 & \\
\hline $\mathrm{LAR}^{\mathrm{ns}}$ & 0.07 & 0.10 & 0.09 & 0.07 & 42.1 \\
\hline $\mathrm{LER}^{\mathrm{ns}}$ & 1.07 & 1.17 & 1.27 & 0.77 & 49.9 \\
\hline $\mathrm{LSR}^{\mathrm{ns}}$ & 0.29 & 0.31 & 0.47 & 0.25 & 128.0 \\
\hline $\mathrm{FLL}^{\mathrm{ns}}$ & 11.92 & 13.60 & 14.23 & 12.53 & 33.7 \\
\hline $\operatorname{LLS}^{\mathrm{ns}}$ & 30.76 & 27.50 & 31.84 & 34.49 & 62.2 \\
\hline $\mathrm{SER}^{\mathrm{ns}}$ & 0.18 & 0.11 & 0.16 & 0.16 & 149 \\
\hline FIL $^{1}$ & 14.83 & 12.11 & 12.75 & 19.35 & 1.87 \\
\hline $\mathrm{NFV}^{1}$ & 3.99 & 4.35 & 4.15 & 2.86 & 0.28 \\
\hline
\end{tabular}

* Mean standard error.

${ }^{n s}$ No significant difference $(\mathrm{P}>0.05) ;{ }^{1}$ significant difference $(\mathrm{P}<0.05)$.

$\mathrm{PHY}=47.3785-4.1867 \mathrm{x}+0.1227 \mathrm{x}^{2} ; \mathrm{r}^{2}=0.99$.

$\mathrm{NLL}=-1.38509+0.70305 \mathrm{x}-0.02133 \mathrm{x}^{2} ; \mathrm{r}^{2}=0.99$.

The non-significance of management height on LAR may be due to a small difference in management height of Aruana grass or the inherent morphophysiological characteristics of the plant and/or environment to which the pasture was exposed. Even under the most adverse environmental conditions or management, LAR is the last variable to be affected. According to Lemaire et al. (2008), in order to maintain tillering development, the economy of photoassimilates would be initiated by reducing tiller density, followed by decreases in leaf length and life span. That is, there is a reduction in the number of tillers and hence LAR to guarantee plant survival under low canopies. Therefore, LAR determines substantial differences in pasture structure due to its effect on tiller size and density (NABINGER; PONTES, 2001). Another factor that may have contributed to a low LAR is that the increase in sheath length of successive leaves in erect growth pastures, such as Aruana grass, leads to a higher delay in leaf appearance (LEMAIRE; CHAPMAN, 1996; GARCEZ NETO et al., 2002).

A negative correlation was observed between LER and LAR so that the lower the LAR is, the higher the LER (SBRISSIA; SILVA, 2001), which could be 
observed in this study. Skinner and Nelson (1995) suggested that leaf elongation is highly influenced by nitrogen supply. However, no difference was observed because fertilization was the same for all treatments, reinforcing the non-significance of results as a function of management heights. The functional plant response may also contribute to limit leaf elongation since each genotype has genetic programming to express its characteristics according to the genotype-environment interaction (OLIVEIRA et al., 2007). The results obtained for LAR and LER corroborate the studies conducted by Oliveira et al. (2007) with Panicum maximum cv. Tanzania and Luna et al. (2014) and Garcez Neto et al. (2002) with Panicum maximum cv. Mombasa, in which no effects were found for cut intensity.

The leaf senescence rate showed no difference between treatments. Studies have indicated that LSR is influenced by the season, with the highest values in the summer (ZANINI et al., 2012). In this sense, the highest elongation rates, tissue renewal and, consequently, higher senescence observed in this study was possible due to the favorable climate conditions (light and temperature) provided by the season the experiment was carried out.

The final leaf length did not affect forage height, probably due to its relationship with LAR and LER. According to Lemaire et al. (2008), the higher the LAR, the shorter the time available for leaf elongation, which would significantly affect FLL. In this case, because any of the influencing variables did not affect grazing height, FLL also had no significant effect $(\mathrm{P}>0.05)$. The negative relationship between LAR and FLL, as described by Nabinger and Pontes (2001), can also corroborate these results because the higher the LAR is, the lower the FLL.

Leaf life span may have been affected by several factors, such as cutting or grazing, climate conditions, plant development stage, and characteristics inherent to the forage species (GARCEZ NETO et al., 2002). This behavior can be better understood when analyzed together with the leaf senescence process (GARCEZ NETO et al., 2002). Once senescence is established, nutrients are remobilized to younger leaves, which reduces the photosynthetic activity of older leaves and leads to a reduction in LLS (OLIVEIRA et al., 2007), corroborating the observations of this study.

Grazing management has been the most used way to control SER, as a high leaf to stem ratio is desired (CORSI et al., 1996). Therefore, SER is also an important morphogenic variable because it causes changes in canopy structure (SILVA; SBRISSIA, 2010). Lower SER values observed in this study corroborate the results obtained in Panicum cultivars found by Luna et al. (2014), which may be associated with a low cutting/grazing height.

The number of live leaves and PHY were influenced (Table 2) by management height of Aruana grass. NLL reached its highest values in the treatments of 12,15 , and $20 \mathrm{~cm}$, ranging from 3.99 to 4.35 . A higher number of live leaves was observed in treatments managed in canopies of lower heights due to the translocation of plant nutrients. According to Bélanger et al. (1992), a higher translocation of photoassimilates to plant shoot is due to the defoliation. Also, this variable can express the potential of a plant to produce and assimilate carbon (POMPEU et al., 2010). In other words, the fact that the canopy was managed with a height of up to $20 \mathrm{~cm}$ allowed a preferential translocation of assimilates to the development of other plant organs, such as stems, to the detriment of increased leaf production (ALEXANDRINO et al., 2005).

Another factor that may have influenced a higher NLL in smaller canopies is the fact that younger leaves usually export a large proportion of assimilates to growing tillers, i.e., a higher defoliation intensity due to the selectivity of the sheep species leads to an increased appearance of new leaves and hence a higher transport of nutrients, generating 
new tiller (ROBSON et al., 1988; BÉLANGER et al., 1992). NLL is a genotypically stable variable directly influenced by LAR and LLS (NABINGER; PONTES, 2001).

In this study, PHY was shorter between heights of 15 to $20 \mathrm{~cm}$ and longer at the height of $25 \mathrm{~cm}$, with values of $12.11,12.75$, and 19.35 , respectively. According to Zanini et al. (2010), it is believed that in younger tillers, younger leaf blades run a shorter distance to expose themselves and, therefore, the time required for the visualization of a new emerged leaf was shorter, resulting in a higher LAR and lower PHY. The opposite can also be observed in the treatment of $25 \mathrm{~cm}$, i.e., the path of the leaf blades in expansion until its emergence was longer, resulting in a longer PHY and lower LAR. These findings and statements corroborate Fournier et al. (2005) because the time interval required for the appearance of two consecutive leaves is directly related to the leaf elongation time, which is dependent on sheath length. Zanini et al. (2012) studied Aruana grass and identified a PHY stability of around 10 to 12 days per leaf when LER was higher than $1.3 \mathrm{~cm} \mathrm{tiller}^{-1}$ day $^{-1}$.

The number of basal and aerial tillers was not influenced by pasture height (Table 3), with a mean value of 5245.7 and 6935.0 tillers $\mathrm{m}^{-2}$, respectively. It can be explained by the management heights adopted due to the used animal species. Initial heights of $40 \mathrm{~cm}$ are usually adopted, but sheep use canopy height as a criterion to establish the grazing site, with a preference for grazing up to eye level (BAZELY, 1990). Thus, the used forage crop resulted in a higher forage tillering, with no difference between treatments. Another factor that may have contributed to this result is the tillering potential of Aruana grass, which could be partially explained by a high leaf appearance rate, which was also observed in Aruana grass by Alcântara et al. (1985) and Cecato et al. (2000).

Table 3. Density of basal and aerial tillers (tillers $\mathrm{m}^{-2}$ ) of Panicum maximum Jacq. Aruana pasture managed at different heights under lamb grazing.

\begin{tabular}{cccccc}
\hline \multirow{2}{*}{ Tiller } & \multicolumn{5}{c}{ Forage height $(\mathrm{cm})$} \\
\cline { 2 - 6 } & 12 & 15 & 20 & 25 & Mean \\
\hline Basal $^{\text {ns }}$ & 5573.2 & 5436.4 & 4960.0 & 5013.2 & 5245.7 \\
Aerial $^{\text {ns }}$ & 7293.2 & 6466.8 & 6826.8 & 7153.2 & 6935.0 \\
\hline
\end{tabular}

${ }^{\mathrm{n}}$ No significant difference $(\mathrm{P}>0.05)$.

Tiller density can be influenced by $\mathrm{N}$ fertilization. However, $\mathrm{N}$ doses were the same for all treatments in this experiment. According to Zarrough (1984), defoliation is another factor that affects tiller density, i.e., lower heights where grazing intensity is higher show a higher density of basal tillers, which is related to the balance between the tiller appearance rate and tiller senescence rate of the forage.

Because no difference was observed between LAR and LSR, no significant effect was observed on the density of basal tillers. However, when assessing aerial tiller, an inverse relationship was observed between LSR and tiller population density, i.e., the lower the LSR is, the higher the density of aerial tillers (SILVA; SBRISSIA, 2010). The direct relationship between LAR and tiller density determines the potential of tillering for a given genotype since each leaf formed on a stem represents the appearance of a new phytomer, i.e., the generation of new axillary buds (DIFANTE, 2003). According to Costa Araújo et al. (2015), the maintenance of similar heights probably did not generate changes in light penetration into the canopy, not influencing tiller density, which is in accordance with the results found here. 


\section{Conclusion}

Management heights from 15 to $20 \mathrm{~cm}$ allowed a higher number of live leaves and a shorter phyllochron in Aruana grass pastures managed for sheep. Canopy height management did not influence other morphogenic characteristics and tiller density.

\section{References}

ALCÂNTARA, V. B. G.; ALMEIDA, A. R. P.; GHISI, O. M. A. Estudos fisiológicos de seis cultivares de Panicum maximum Jacq. Boletim de Indústria Animal, Nova Odessa, v. 42, n. 2, p. 199-208, 1985.

ALEXANDRINO, E.; CÂNDIDO, M. J. D.; GOMIDE, J. A. Fluxo de biomassa e taxa de acúmulo de forragem em capim Mombaça mantido sob diferentes alturas. Revista Brasileira de Saúde e Produção Animal, Salvador, v. 12, n. 1, p. 59-71, 2011.

ALEXANDRINO, E.; GOMIDE, J. A.; OLIVEIRA, J. A.; TEIXEIRA, A. C. B.; LANZA, D. C. F. Distribuição dos fotoassimilados em plantas de Panicum maximum cv. Mombaça. Revista Brasileira de Zootecnia, Viçosa, MG, v. 34 , n. 5 , p. $1449-1458$, 2005. DOI: $10.1590 /$ S151635982005000500004

ALVARES, C. A.; STAPE, J. L.; SENTELHAS, P. C.; GONÇALVES, J. L. M.; SPAROVEK, G. Koppen's climate classification map for Brazil. Meteorologische Zeitschrift, Stuttgart, v. 22, n. 6, p. 711-728, 2013. DOI: 10.1127/0941-2948/2013/0507

BAZELY, D. R. Rules and cues used by sheep foraging in monocultures. In: HUGUES, R. N. (Ed.). Behavioral mechanisms of food selection. Berlin: NATO ASI Series, 1990. p. 343-366.

BÉLANGER, G.; GASTAL, F.; LEMAIRE, G. Growth analysis of a Tall Fescue sward fertilized with different rates of nitrogen. Crop Science, Guilford, v. 32, n. 6, p. 1371-1376, 1992. DOI: 10.2135/cropsci1992.0011183X $003200060013 x$

BIACHINI, D.; CARRIEL, J. M.; LEINZ, F. F.; RODRIGUES, C. F. C. Viabilidade de doze capins tropicais para criação de ovinos. Boletim de Indústria Animal, Nova Odessa, v. 56, n. 2, p. 163-177, 1999.

CARRÈRE, P.; LOUAULT, F.; SOUSSANA, J. F. Tissue turnover within grass-clover mixed swards grazed by sheep fluxes. Journal of Applied Ecology, London, v. 34, n. 2 , p. $333-348,1997$. DOI: $10.2307 / 2404880$

CECATO, U.; MACHADO, A. O.; MARTINS, E. N.; PEREIRA, L. A. F.; BARBOSA, M. A. A. F.; SANTOS,
G. T. Avaliação da produção e de algumas características da rebrota de cultivares e acessos de Panicum maximum Jacq. Sob duas alturas de corte. Revista Brasileira de Zootecnia, Viçosa, MG, v. 29, n. 3, p. 660-668, 2000. DOI: $10.1590 / \mathrm{S} 1516-35982000000300004$

CORSI, M.; SILVA, S. C.; FARIA, V. P. Princípios de manejo do Capim-Elefante sob pastejo. In: PEIXOTO, A. M.; MOURA, J. C.; FARIA, V. P. (Ed.). Pastagens de Capim-Elefante: utilização intensiva. Piracicaba: FEALQ, 1996. p. 51-70.

COSTA ARAÚJO, D. L.; OLIVEIRA, M. E.; LOPES, J. B.; ALVES, A. A.; RODRIGUES, M. M.; MOURA, R. L.; SANTOS, M. S. Características morfogênicas, estruturais e padrões demográficos de perfilhos em pastagem de capim-andropógon sob diferentes ofertas de forragem. Semina: Ciências Agrárias, Londrina, v. 36, n. 5, p. 3303-3314, 2015. DOI: 10.5433/1679-0359.2015v3 6n5p3303

DIFANTE, G. S. Importância da morfogênese no manejo de gramíneas forrageiras. Viçosa, MG: Editora UFV, 30 p., 2003. Disponível em: http:www.forragicultura.com. br. Acesso em: 27 jul. 2016.

EMPRESA BRASILEIRA DE PESQUISA AGROPEUÁRIA - EMBRAPA. Centro Nacional de Pesquisa dos Solos. Sistema Brasileiro de classificação dos solos. Rio de Janeiro, Embrapa solos. 1999. 412p.

FOURNIER, C.; DURAND, J. L.; LJUTOVAC, S.; SCHÄUFELE, R.; GASTAL, F.; ANDRIEU, B. Functional-structural model of elongation of the grass leaf and its relationships with the phyllochron. New Phytologist, Lancaster, v. 166, n. 3, p. 881-894, 2005. DOI: $10.1111 / j .1469-8137.2005 .01371 . x$

GARCEZ NETO, A. F.; NASCIMENTO JUNIOR, D.; REGAZZI, A. J.; FONSECA, D. M.; MOSQUIM, P. R.; GOBBI, K. F. Respostas morfogênicas e estruturais de Panicum maximum cv. Mombaça sob diferentes níveis de adubação nitrogenada e alturas de corte. Revista Brasileira de Zootecnia, Viçosa, MG, v. 31, n. 5, p. 18901900, 2002. DOI: 10.1590/S1516-35982002000800004

GOMIDE, J. A.; GOMIDE, C. A. M. Fundamentos e estratégia do manejo de pastagens. In: SIMPÓSIO DE PRODUÇÃO DE GADO DE CORTE, 1999, Viçosa, MG. Anais... Viçosa, MG: UFV, 1999. p. 179-200.

INSTITUTO NACIONAL DE METEOROLOGIA INMET. Consulta de dados da estação automática. Dois Vizinhos: [s.n.], 2013. Disponível em: http://www.inmet. gov.br/sonabra/pg_dspDadosCodigo.php?QT g0Mw. Acesso em: 15 fev. 2013.

LEMAIRE, G.; CHAPMAN, D. Tissue flows in grazed plant communities. In: HODGSON, J.; ILLUS, A. W. 
(Ed.). The ecology and management of grazing systems. Oxon: CAB International, 1996. p. 3-36.

LEMAIRE, G.; OOSTEROM, E. V.; JEUFFROY, M. H.; GASTAL, F.; MASSIGNAM, A. Crop species present different qualitative types of response to $\mathrm{N}$ deficiency during their vegetative growth. Field Crops Research, Amsterdam, v. 105, n. 3, p. 253-265, 2008. DOI: 10.1016/j.fcr.2007.10.009

LUNA, A. A.; DIFANTE, G. S.; MONTAGNER, D. B.; EMERENCIANO NETO, J. V.; ARAUJO, I. M. M.; OLIVEIRA, L. E. C. Características morfogênicas e acúmulo de forragem de gramíneas forrageiras, sob corte. Bioscience Journal, Uberlândia, v. 30, n. 6, p. 1803-1810, 2014.

MOTT, G. O.; LUCAS H. L. The design, conduct, and interpretation of grazing trials on cultivated and improved pastures. In: INTERNATIONAL GRASSLAND CONGRESS, 6., 1952, Pennsylvanian. Proceedings... Pennsylvanian: State College, 1952. p. 1380-1385.

NABINGER, C.; PONTES, L. S. Morfogênese de plantas forrageiras e estrutura do pasto. In: REUNIÃO DA SOCIEDADE BRASILEIRA DE ZOOTECNIA, 38., 2001, Piracicaba. Anais... Piracicaba: SBZ, 2001. p. 755-771.

OLIVEIRA, A. B.; PIRES, A. S. V.; MATOS NETO, U.; CARVAlHO, G. G. P.; VElOSO, C. M.; SILVA, F. F. Morfogênese do capim-Tanzânia submetido a adubações e intensidade de corte. Revista Brasileira de Zootecnia, Viçosa, MG, v. 36, n. 4, p. 1006-1013, 2007. Suplemento. DOI: $10.1590 / \mathrm{S} 1516-35982007000500004$

POMPEU, R. C. F. F.; CÂNDIDO, M. J. D.; LOPES, M. N.; GOMES, F. H. T.; LACERDA, C. F.; AQUINO, B. F.; MAGALHÃES, J. A. Características morfofisiológicas do capim-Aruana sob diferentes doses de nitrogênio. Revista Brasileira de Saúde e Produção Animal, Salvador, v. 11, n. 4, p. 1187-1210, 2010.

R CORE TEAM - R: a language and environment for statistical computing. Vienna: $\mathrm{R}$ Foundation for Statistical Computing, 2013.

ROBSON, M. J.; RYLE, G. J. A.; WOLEDGE, J. The grass plant - its form and function. In: JONES, M. B.; LAZENBY, A. (Ed.). The grass crop: the physiological basis of production. London: Chapman and Hall, 1988. p. 25-83.

SBRISSIA, A. F.; SILVA, S. C. da. O ecossistema de pastagens e a produção animal In: REUNIÃO ANUAL DA SOCIDADE BRASILEIRA DE ZOOTECNIA, 38., 2001. Anais... Piracicaba: SBZ, 2001. p.731-754.

SILVA, C. C. F.; BONOMO, P.; PIRES, A. J. V.; MARANHÃO, C. M. A.; PATÊS, N. M. S.; SANTOS,
L. C. Características morfogênicas e estruturais de duas espécies de braquiária adubadas com diferentes doses de nitrogênio. Revista Brasileira de Zootecnia, Viçosa, MG, v. 38, n. 4, p. 657-661, 2009. DOI: 10.1590/S151635982009000400010

SILVA, S. C.; SBRISSIA, A. F. Análise de componentes principais entre características morfogênicas e estruturais em capim-Marandú sob lotação contínua. Ciência Rural, Santa Maria, v. 40, n. 3, p. 690-693, 2010. DOI: 10.1590/ S0103-84782010000300034

SKINNER, R. H.; NELSON, C. J. Elongation of the grass leaf and its relationship to the phyllochron. Crop Science, Guilford, v. 35, n. 1, p. 4-10, 1995. DOI: 10.2135/cropsc i1995.0011183X003500010002x

SOUSA, B. M. L.; SANTOS, M. E. R.; VILELA, H. H.; SILVEIRA, M. C. T.; ROCHA, G. O.; FREITAS, C. A. S.; SILVA, N. A. M.; NASCIMENTO JUNIOR, D. Piatã palisade grass deferred with two distinct initial heights: luminous environment and tillering dynamics. Revista Brasileira de Zootecnia, Viçosa, MG, v. 42, n. 1, p. 3643, 2013. DOI: 10.1590/S1516-35982013000100006

VILELA, H. H.; SOUSA, B. M. L.; SANTOS, M. E. R.; SANTOS, A. L.; ASSIS, C. Z.; ROCHA, G. O.; FARIA, B. D.; NASCIMENTO JUNIOR, D. Forage mass and structure of Piatã grass deferred at different heights and variable periods. Revista Brasileira de Zootecnia, Viçosa, MG, v. 41, n. 7, p. 1625-1631, 2012. DOI: 10.1590/ S1516-35982012000700010

ZANINI, G. D.; SANTOS, G. T.; PADILHA, D. A.; CIZINANDE, S.; SILVA, D.; BORGES, J. A. S.; SILVA, M. C.; FREITAS, R. C.; ARRUDA, J. C. A.; ALMEIDA, G.; NASCIMENTO JUNIOR, D.; SILVA, S. C.; SBRISSIA, A. F. Morphological characteristics and tiller population density of Aruana guinea grass subjected to frequencies and severities of grazing by sheep. In: GENERAL MEETING OF THE EUROPEAN GRASSLAND FEDERATION - GRASSLAND IN A CHANGING WORLD, 23., 2010, Kiel - Alemanha. Proceedings... Duderstadt: Mecke Druck und Verlag, 2010. p. 1006-1008.

ZANINI, G. D.; SANTOS, G. T.; SBRISSIA, A. F. Frequencies and intensities of defoliation in Aruana Guinea grass swards: morphogenetic and structural characteristics. Revista Brasileira de Zootecnia, Viçosa, MG, v. 41, n. 8, p. 1848-1857, 2012. DOI: 10.1590/ S1516-35982012000800007

ZARROUGH, K. M.; NELSON, C. J.; SLEPER, D. A. Interrelation chips between rates of leaf appearance and tittering in selected tall fescue populations. Crop Science, Guilford, v. 24, n. 1, p. 565-569, 1984. DOI: 10.2135/cro psci1984.0011183X002400030032x 
